\section{Syntheses of Oxanosine and Carbocyclic Oxanosine Derivatives as Anti-HIV Agents}

\author{
Yoshio Saito $^{\mathrm{a}}$, Mariko Nakamura ${ }^{\mathrm{b}}$, Tsuneya OHno ${ }^{\mathrm{b}}$, \\ Chanya ChaICHAROENPONG ${ }^{\mathrm{a}}$, EIKO ICHIKAWA ${ }^{\mathrm{c}}$, \\ ShOSUKE YAMAMURA ${ }^{c}$, KUNIKI KaTO ${ }^{d}$ \\ and KAZUO UMEZAWA ${ }^{\text {a,* }}$ \\ Departments of a Applied Chemistry and ${ }^{\mathrm{c}}$ Chemistry, \\ Faculty of Science and Technology, Keio University \\ 3-14-1 Hiyoshi, Kohoku-ku, Yokohama 223-0061, Japan \\ ${ }^{b}$ Department of Microbiology, \\ Jikei University School of Medicine \\ 3-25-8 Nishi-Shinbashi, Minato-ku, Tokyo 105-8461, Japan \\ ${ }^{d}$ Research Laboratories, Pharmaceuticals Group, \\ Nippon Kayaku Co, Ltd. \\ 3-31 Shimo, Kita-ku, Tokyo 115-0042, Japan
}

(Received for publication December 2, 1999)

Since the discovery of AZT in 1985, ${ }^{\text {,) }}$ many kinds of sugar-modified nucleoside analogs have been synthesized for potential use as anti-HIV agents. At present, AZT, $\mathrm{ddI}, \mathrm{ddC}, \mathrm{d} 4 \mathrm{~T}$, and (-)-3TC are approved for the clinical treatment of AIDS and AIDS-related complex, and several other sugar-modified nucleosides, e.g., carbovir (carbocyclic 2',3'-didehydro-2', $3^{\prime}$-dideoxyguanosine) are undergoing clinical or preclinical development. ${ }^{2}{ }^{2}$ However, it is still necessary to search for new anti-HIV agents that are more potent and less toxic. Moreover, drug-resistant HIVs continue to emerge rapidly.

Oxanosine 1, a novel guanosine analog antibiotic isolated from the culture broth of Streptomyces capreolus MG265CF3 has been reported to show antibacterial activity and to inhibit growth of HeLa cells in culture. ${ }^{3)}$ Furthermore, 1 has been proved to alter tumor cell morphology into normal morphology in temperature-sensitive K-ras transformed rat kidney (K-ras ${ }^{\text {ts }}-\mathrm{NRK}$ ) cells by inhibiting inosine monophosphate (IMP) dehydrogenase ${ }^{4)}$ On the other hand, no anti-viral effect of oxanosine has been reported. In order to find new anti-HIV agents, we have synthesized a series of derivatives of oxanosine $\mathbf{1}$ and carbocyclic oxanosine $\mathbf{5}$. In this report we describe the syntheses and structureactivity relationships of oxanosine and carbocyclic oxanosine derivatives as anti-HIV agents.

Individual steps leading to the target oxanosine derivatives are summarized in Scheme 1. After protection of the $5^{\prime}$-hydroxyl group of 1 with $t$-butyldimethylsilyl chloride, treatment of $\mathbf{1 0}$ with thiocarbonyldiimidazole in dichloroethane afforded thiocarbonate 11, which was then refluxed with trimethyl phosphite to provide olefin $12^{5)}$ Deprotection of 12 with $n \mathrm{Bu}_{4} \mathrm{NF}$ gave $2^{\prime}, 3^{\prime}$-didehydro$2^{\prime}, 3^{\prime}$-dideoxyoxanosine $\mathbf{2}$ in $84 \%$ overall yield. Compound 2 was hydrogenated over $10 \% \mathrm{Pd} / \mathrm{C}$ in $\mathrm{MeOH}$ to give $2^{\prime}, 3^{\prime}$ dideoxyoxanosine 3. Oxanosine 5'-monophosphate 4 could be easily obtained from 1 by treatment with phosphoryl chloride in trimethyl phosphate. ${ }^{6)} 2^{\prime}$-Deoxyoxanosine 9 was prepared from 1 in 4 steps according to known procedures. ${ }^{7}$

The synthetic route used to prepare carbocyclic oxanosine and its analogs is illustrated in Scheme 2. (-)2-Azabicyclo[2,2,1]hept-5-en-3-one $\mathbf{1 3}$ was first converted to the Boc compound $\mathbf{1 4}$ according to the protocol of HUTCHINSON et al..$^{8}$ When compound $\mathbf{1 4}$ was treated with chloromethyl methyl ether in the presence of $N, N$-diisopropylethylamine, methoxymethyl compound 15 was obtained in $88 \%$ yield. Hydrolysis of $\mathbf{1 5}$ with $\mathrm{H}_{2} \mathrm{O}^{8)}$ followed by treatment with ethyl $\mathrm{N}$ (ethoxycarbonylcyanomethyl) formimidate ${ }^{9)}$ furnished the imidazole $\mathbf{1 6}$ in $62 \%$ yield in 2 steps. Then, compound $\mathbf{1 6}$ was reacted with ethoxycarbonyl isothiocyanate to give the thiourea 17 in $93 \%$ yield, which with methyl iodide in $0.1 \mathrm{~N}$ sodium hydroxide yielded the methylthio derivative 18 in $99 \%$ overall yield. Cyclization of compound 18 with $5 \mathrm{~N}-$ methanolic KOH under reflux for 30 minutes followed by neutralization of the reaction mixture with $4 \mathrm{~N}-\mathrm{HCl}$ afforded

Fig. 1. Structure of oxanosine and carbocyclic oxanosine derivatives.<smiles>[X]C1C(O)C(O)C(O)C1n1cnc2c(=O)oc(N)nc21</smiles>

1, $\mathrm{X}=\mathrm{O}$ : oxanosine

5, $\mathrm{X}=\mathrm{CH}_{2}$ : carbocyclic oxanosine

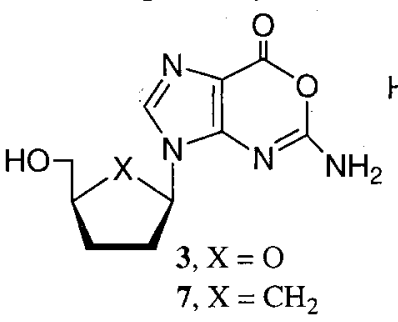<smiles>[X]C1(O)C2C=CC1N1c3nc(N)oc(=O)c3N=CN21</smiles>

$2, \mathrm{X}=\mathrm{O}$

6, $\mathrm{X}=\mathrm{CH}_{2}$<smiles></smiles>

4, $\mathrm{X}=\mathrm{O}$

8, $\mathrm{X}=\mathrm{CH}_{2}$ 
Scheme 1.

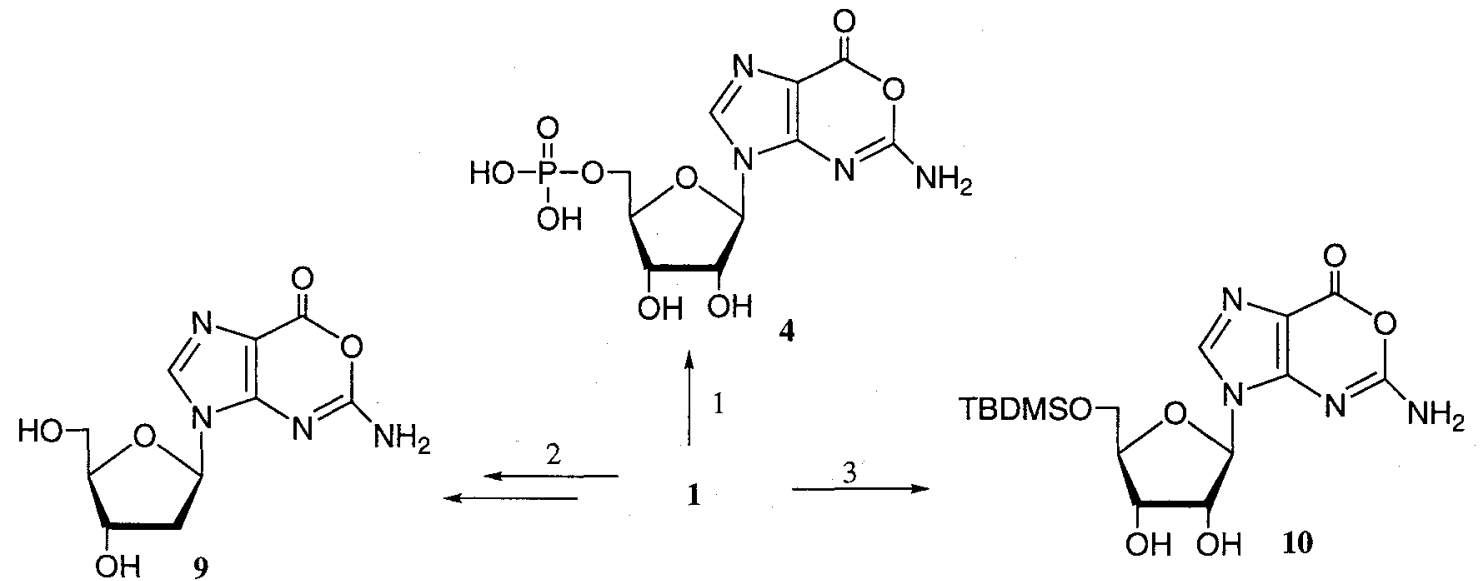<smiles>CC(C)CCOC1OC2C=CC1C1OC(=S)OC1C2n1cnc2c(=O)oc(N)nc21</smiles>

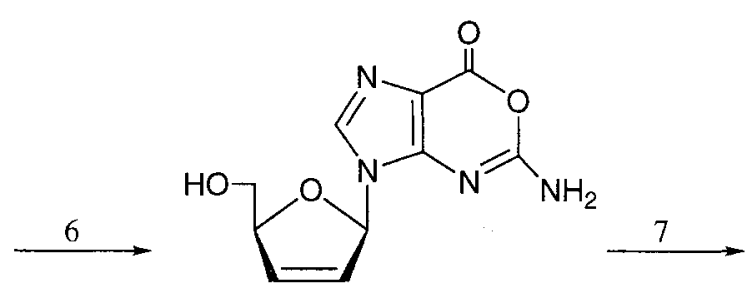

2<smiles>Nc1nc2c(ncn2[C@H]2C[C@H]3CO[C@H]2O3)c(=O)o1</smiles>

3

Reagents and conditions: 1) $\mathrm{PO}(\mathrm{OMe})_{3}, \mathrm{POCl}_{3}, 0^{\circ} \mathrm{C}, 2$ hours, 93\% yield; 2) 4 steps see ref. 7; 3) TBDMSCl, pyridine, rt, 2 hours, 90\%; 4) TCDI, $\mathrm{ClCH}_{2} \mathrm{CH}_{2} \mathrm{Cl}$, rt, 4 hours, 67\%; 5) $\mathrm{P}(\mathrm{OMe})_{3}, 120^{\circ} \mathrm{C}, 1.5$ hours, $76 \%$; 6$) n \mathrm{Bu}_{4} \mathrm{NF}$, THF, rt, 1 hour, 84\%; 7) $\mathrm{H}_{2}, 10 \% \mathrm{Pd} / \mathrm{C}, \mathrm{MeOH}, \mathrm{rt}, 3$ hours, $81 \%$.

imidazo-oxazinone 19 in $45 \%$ yield. Carbocyclic oxanosine 5 could be prepared from compound $\mathbf{1 9}$ by treatment with aqueous trifluoroacetic acid in $99 \%$ yield. Carbocyclic oxanosine $5^{\prime}$-monophosphate $\mathbf{8}$ was prepared from $\mathbf{5}$ by the same method described for 4 in 44\% yield.

By employing similar reactions to those described for compound 5 from 13, we obtained carbovir-type oxanosine analog 6 from compound 20 in 5 steps. Under neutral hydrogenation conditions with $10 \% \mathrm{Pd} / \mathrm{C}$ in $\mathrm{EtOH}$, compound 6 afforded dideoxy carbocyclic oxanosine 7 in $92 \%$ overall yield.

The anti-HIV-1 activity and cytotoxicity of the newly synthesized oxanosine and carbocyclic oxanosine derivatives were evaluated in vitro on human $\mathrm{T}$ cell leukemia CEM, H9, and U937 cell lines as shown in Table 1. The former two were used for an acute infection assay to evaluate the effect on HIV replication, especially the early steps in the infection process, and the latter, for a chronic infection assay to evaluate the decrease in HIV production from cells whose infection had already been established. In an acute assay CEM cells were more sensitive than $\mathrm{H} 9$ cells to AZT and oxanosine derivatives. Oxanosine itself showed anti-HIV activity in acute and chronic assays. Compounds 4 and 9 were found to demonstrate stronger acute anti-HIV activity than oxanosine in $\mathrm{CEM}$ cells with $\mathrm{EC}_{50}$ values of 4.1 and $4.8 \mu \mathrm{g} / \mathrm{ml}$, respectively, without cytotoxicity up to 
Scheme 2.

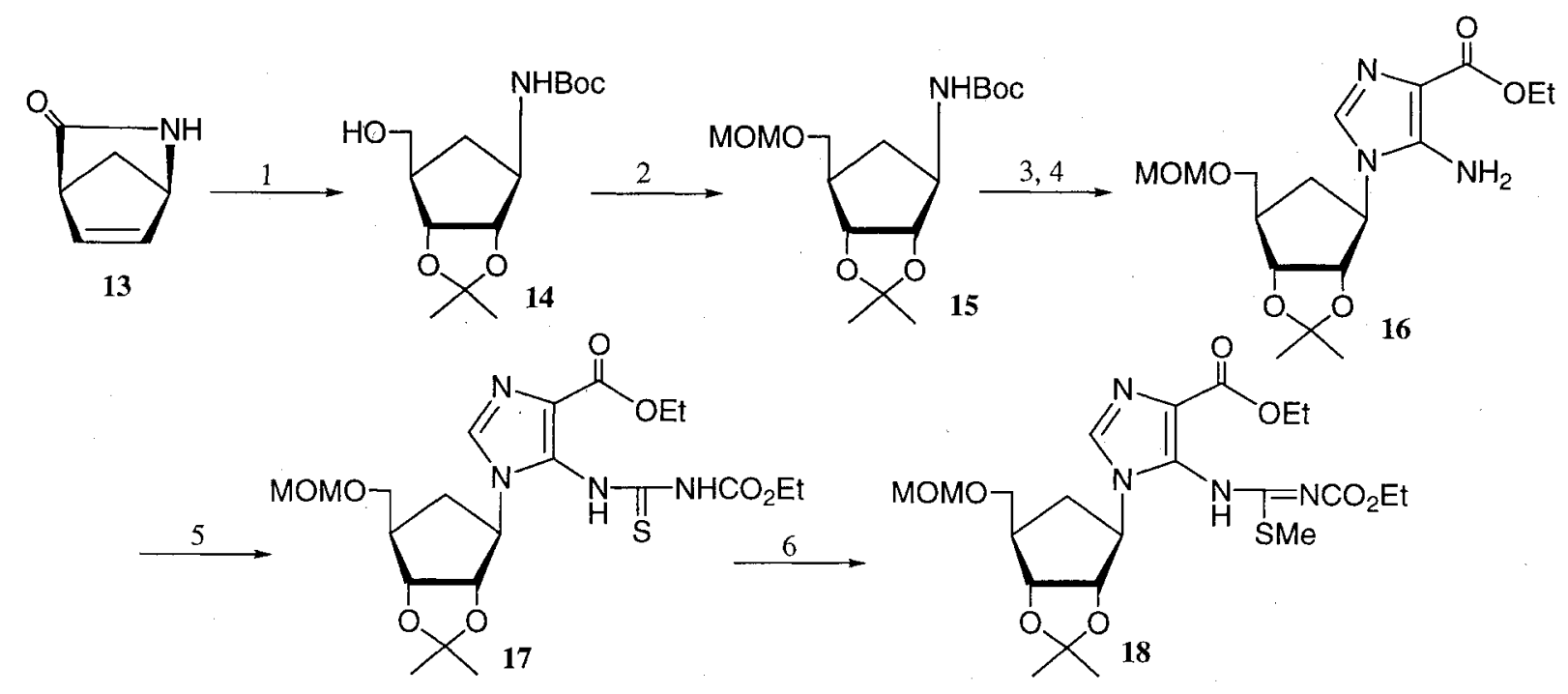<smiles></smiles>

Reagents and conditions: 1) 4 steps see ref. 8 ; 2) $\mathrm{ClCH}_{2} \mathrm{OCH}_{3}, \mathrm{~N}, \mathrm{~N}$-diisopropylethylamine, $\mathrm{CH}_{2} \mathrm{Cl}_{2}$, rt, 5 hours, $88 \%$; 3) $\mathrm{H}_{2} \mathrm{O}$, reflux, 6 hours; 4) $\mathrm{EtO}-\mathrm{CH}=\mathrm{N}-\mathrm{CH}(\mathrm{CN}) \mathrm{CO}_{2} \mathrm{Et}$, reflux, 15 minutes, $62 \%$ in 2 steps; 5 ) EtOCONCS, $\mathrm{CH}_{3} \mathrm{CN}$, reflux, 2 hours, 93\%; 6) MeI, $0.1 \mathrm{~N}-\mathrm{NaOH}, \mathrm{MeOH}, \mathrm{rt}, 1$ hour, 99\%; 7) $5 \mathrm{~N}$-methanolic $\mathrm{KOH}$, reflux, 30 minutes, then $4 \mathrm{~N}-\mathrm{HCl}, \mathrm{rt}, 10$ mimutes, $45 \% ; 8) \mathrm{TFA}: \mathrm{H}_{2} \mathrm{O}=3: 1,50^{\circ} \mathrm{C}, 3$ hours, 99\%; 9) $\mathrm{PO}(\mathrm{OMe})_{3}, \mathrm{POCl}_{3}, 0^{\circ} \mathrm{C}, 2$ hours, $44 \%$.

Scheme 3.<smiles>CCOC(=O)c1ncn([C@H]2C=C[C@H](CO)C2)c1N</smiles>

Reagents and conditions: 1) $90 \%$ TFA, rt, 15 minutes; 2) $\mathrm{EtO}-\mathrm{CH}=\mathrm{N}-\mathrm{CH}(\mathrm{CN}) \mathrm{CO}_{2} \mathrm{Et}$, reflux, 15 minutes, $79 \%$ in 2 steps; 3) EtOCONCS, $\mathrm{CH}_{3} \mathrm{CN}$, reflux, 1 hour, $88 \%$; 4) MeI, $0.1 \mathrm{~N}-\mathrm{NaOH}, \mathrm{MeOH}, \mathrm{rt}, 1$ hour, $92 \%$; 5) $5 \mathrm{~N}$-methanolic $\mathrm{KOH}$, reflux, 30 minutes, then $4 \mathrm{~N}-\mathrm{HCl}, 56 \%$; 6) $\mathrm{H}_{2}, 10 \% \mathrm{Pd} / \mathrm{C}, \mathrm{EtOH}, \mathrm{rt}, 14$ hours, $92 \%$. 
Table 1. Inhibition of HIV-1 replication by oxanosine derivatives.

\begin{tabular}{|c|c|c|c|c|c|c|}
\hline \multirow[b]{2}{*}{ compound } & \multicolumn{2}{|c|}{ CEM cells (acute ${ }^{\mathrm{a}}$ ) } & \multicolumn{2}{|c|}{ H9 cells (acute ${ }^{\mathrm{a}}$ ) } & \multicolumn{2}{|c|}{ U937 cells (chronic ${ }^{\mathrm{b}}$ ) } \\
\hline & $\mathrm{EC}_{50}{ }^{\mathrm{c}}(\mu \mathrm{g} / \mathrm{ml})$ & $\mathrm{CC}_{50}{ }^{\mathrm{d}}(\mu \mathrm{g} / \mathrm{ml})$ & $\mathrm{EC}_{50}$ & $\mathrm{CC}_{50}$ & $\mathrm{EC}_{50}$ & $\mathrm{CC}_{50}$ \\
\hline 1 & 7.0 & 440 & $>500$ & $>500$ & 27 & $>100$ \\
\hline 2 & 11 & 300 & 155 & $>500$ & 13 & 56 \\
\hline 3 & $>500$ & $>500$ & $>500$ & $>500$ & $>100$ & $>100$ \\
\hline 4 & 4.1 & $>500$ & $>500$ & $>500$ & 21 & $>100$ \\
\hline 5 & 240 & $>500$ & $>500$ & $>500$ & $>100$ & $>100$ \\
\hline 6 & 42 & $>500$ & 320 & $>500$ & 41 & $>100$ \\
\hline 7 & 170 & $>500$ & 175 & $>500$ & 36 & $>100$ \\
\hline 8 & 62 & $>500$ & $>500$ & $>500$ & $>100$ & $>100$ \\
\hline 9 & 4.8 & $>500$ & $>500$ & $>500$ & $>100$ & $>100$ \\
\hline ddI & 2.6 & $>500$ & 1.6 & $>500$ & 39 & $>100$ \\
\hline AZT & 0.0018 & $>500$ & 0.052 & $>500$ & 9.4 & $>100$ \\
\hline
\end{tabular}

\begin{abstract}
${ }^{a}$ To evaluate anti-HIV activities toward acute infection, we used HIV-1 IIIB strain and CEM or H9 cells. The cells were pretreated with the compounds for $30 \mathrm{~min}$ and then infected by HIV at a multiplicity of 0.05 . Cells were incubated for $90 \mathrm{~min}$ with virus and then diluted with fresh medium 1:10 for culturing. On day 6 , the culture fluid was harvested for reverse transcriptase (RT) and MTT assays. ${ }^{\mathrm{b}}$ To evaluate anti-HIV activities toward chronic infection, we used HIV-1 IIIB strain and U937 cells. Chronically infected cells were seeded in the presence of the compounds and harvested at 96 hours for RT and MTT assays. ${ }^{c}$ Effective concentration required to inhibit HIV-1 reverse transcriptase activity by $50 \%$. ${ }^{\mathrm{d}} 50 \%$ cytotoxic concentration.
\end{abstract}

$500 \mu \mathrm{g} / \mathrm{ml}$. These activities were comparable to that of $\mathrm{ddI}$ $\left(\mathrm{EC}_{50}, 2.6 \mu \mathrm{g} / \mathrm{ml}\right)$. Compound 4 was stronger than oxanosine 1, and $\mathbf{8}$ was stronger than $\mathbf{5}$. This may be because cellular phosphorylation is necessary for these unusual nucleosides to inhibit reverse transcriptase. Carbocyclic oxanosine 5 and its phosphate $\mathbf{8}$ were weaker than 1 and 4 , suggesting that the hydrofuran structure is essential. Oxanosine and related compounds showed only weak activity in H9 cells, although ddI exhibited anti-HIV activity with an $\mathrm{EC}_{50}$ value of $1.6 \mu \mathrm{g} / \mathrm{ml}$ in this cell line.

The chronic assay is considered to be closer to the clinical situation than the acute assay. Interestingly, oxanosine 1 and 4 also exhibited chronic anti-HIV-1 activity with $\mathrm{EC}_{50}$ values of 27 and $21 \mu \mathrm{g} / \mathrm{ml}$, respectively, without cytotoxicity up to $100 \mu \mathrm{g} / \mathrm{ml}$ in $\mathrm{U} 937$ cells. Although 2 also showed activity $\left(\mathrm{EC}_{50}, 13 \mu \mathrm{g} / \mathrm{ml}\right)$, it exhibited cytotoxicity with a $\mathrm{CC}_{50}$ value of $56 \mu \mathrm{g} / \mathrm{ml}$.

Thus, oxanosine and its derivatives showed anti-HIV activity in cellular acute and chronic assays. Oxanosine derivatives were more potent than the carbocyclic counterparts. The mechanism of anti-HIV effect is being studied.

\section{References}

1) Mitsuya, H.; K. J. Weinhold, P. A. Furman, M. H. St Clair, S. N. Lehrman, R. C. Gallo, D. Bolognesi, D. W. BARry \& S. BRoder: 3'-Azide-3'-deoxythymidine (BW A509U): an antiviral agent that inhibits the infectivity and cytopathic effect of human Tlymphotropic virus type III/lymphadenopathy-associated virus in vitro. Proc. Natl. Acad. Sci. USA 82: 7096 7100, 1985

2) VincE, R. \& M. HuA: Synthesis and anti-HIV activity of carbocyclic 2',3'-dideoxy 2,6-disubstituted purine nucleosides. J. Med. Chem. 33: 17 21, 1990

3) Shimada, N.; N. Yagisawa, H. Naganawa, T. Takita, M. Hamada, T. Takeuchi \& H. Umezawa: Oxanosine, a novel nucleoside from actinomycetes. J. Antibiotics 34: 1216 1218, 1981

4) Itoh, O; S. Kuroiwa, S. Atsumi, K. Umezawa, T. TAKEUCHI \& M. HORI: Induction by the guanosine analogue of revrsion toward the normal phenotype of K-ras-transformed Rat kidney cells. Cancer Res. 49: 996 1000, 1989

5) CRISP, G. T. \& B. L. FLYNN: Approaches to sugar modified 5-trifluoromethanesulfonylpyrimidine nucleosides. Tetrahedron 49: 5873 5890, 1993

6) Yoshikawa, M.; T. Kato \& T. Takenishi: A novel method for phosphorylation of nucleosides to $5^{\prime}$ nućleotides. Tetrahedron Lett. 7: 5065 5068, 1967

7) Kato, K.; N. Yagisawa, N. Shimada, M. Hamada, T. TAKITA, K. MAEDA \& H. UMEZAWA: Chemical modification of oxanosine I. Synthesis and biological 
properties of 2'-deoxyoxanosine. J. Antibiotics 37: $941 \sim 942,1984$

8) Hutchinson, E. J.; B. F. Taylor \& G. M. Blackburn: Synthesis of carbocyclic $\mathrm{NAD}^{+}$containing a methylenebisphosphonate linkage for the investigation of ADP-ribosyl cyclase. Chem. Commun.: 2765 2766, 1996.
9) Robinson, D. H. \& G. SHaw: Purines, pyrimidines, and imidazoles. Part XXXIX. Formation of some 5aminoimidazole-4-carboxylic acid derivatives from ethyl $\alpha$-amino- $\alpha$-cyanoacetate. J. Chem. Soc., Perkin Trans. 1: $1715 \sim 1717,1972$ 